\title{
Inclusive Inquiry: An Innovative Approach for Promoting Inclusion in Schools
}

\section{Investigación Inclusiva: Un Enfoque Innovador para Promover la Inclusión en las Escuelas}

\author{
Kyriaki Messiou 1, * \\ Mel Ainscow ${ }^{2}$ \\ ${ }^{1}$ University of Southampton, Reino Unido \\ ${ }^{2}$ University of Manchester, Reino Unido
}

\begin{abstract}
This article describes Inclusive Inquiry, a new approach that emerged from our earlier work, particularly two interconnected studies funded by the European Union. These studies were conducted in primary and secondary schools in five countries. We explain how the approach was developed, using examples from schools that were involved. A particular feature of the approach is the involvement of students in schools as researchers, who collaborate with their teachers and classmates in designing inclusive lessons. The approach has been found to be a powerful way of teacher professional learning, whilst at the same time developing ways of ensuring that all children are included in lessons. This suggests that inclusion is less about the introduction of particular techniques, or new organisational arrangements, and much more about processes of social learning within particular contexts. In this respect, the use of evidence as a means of stimulating experimentation and collaboration is a central strategy. We conclude that this has significant implications for leadership practice within schools. In particular, it calls for efforts to encourage coordinated and sustained efforts around the idea that changing outcomes for vulnerable groups of students is unlikely to be achieved without changes in relationships between students and teachers.
\end{abstract}

Keywords: Inclusive education; Teacher professional learning; Students' voices; Dialogue; Schools.

Este artículo describe la investigación inclusiva, un nuevo enfoque que surgió de nuestro trabajo previo, se refiere particularmente a dos estudios interconectados financiados por la Unión Europea. Estos estudios se realizaron en escuelas primarias y secundarias de cinco países. Explicamos cómo se desarrolló el enfoque, utilizando ejemplos de las escuelas participantes. Una característica particular del enfoque es la participación de los estudiantes como investigadores, quienes colaboran con sus maestros y compañeros de clase en el diseño de lecciones inclusivas. Se ha descubierto que este enfoque es una forma poderosa de aprendizaje profesional docente, al mismo tiempo, desarrolla formas de asegurar que todos los niños estén incluidos en las clases. Esto sugiere que la inclusión tiene menos que ver con la introducción de técnicas específicas, o nuevos arreglos organizativos, y mucho más con procesos de aprendizaje social dentro de contextos particulares. En este sentido, el uso de la evidencia como medio para estimular la experimentación y la colaboración es una estrategia central. Concluimos que esto tiene significativas implicancias para la práctica del liderazgo dentro de las escuelas. En especial, implica esfuerzos para alentar acciones coordinadas y sostenidas en torno a la idea de que es poco probable que se logren cambios en los resultados de los grupos vulnerables de estudiantes sino ocurren cambios en las relaciones entre estudiantes y docentes.

Descriptores: Educación inclusiva; Aprendizaje profesional docente; Voces de los estudiantes; Diálogo; Escuelas. 


\section{Introduction}

Over the last 30 years there have been major international efforts to encourage inclusive educational developments. In particular, the United Nation's Education for All (EFA) movement has worked to make quality basic education available to all learners. The year 2016 was particularly significant in taking this global reform agenda forward. Building on the Incheon Declaration agreed at the World Forum on Education in May 2015, it saw the publication of the Education 2030 Framework for Action (UNESCO, 2015). This emphasises inclusion and equity as laying the foundations for quality education.

Despite these developments, a recent Global Monitoring Report points out that an estimated 258 million children, adolescents and youth are still not in school (UNESCO, 2020). Furthermore, the UNESCO Institute for Statistics data show that more than 617 million children and adolescents are not achieving minimum proficiency levels in reading and mathematics (UIS, 2019). Meanwhile, many young people leave school with no worthwhile qualifications, whilst others are placed in special provision away from mainstream education and some choose to drop out since the lessons seem irrelevant (OECD, 2012).

What, then, can be done to support practitioners in responding to these massive challenges? In this paper we describe the development of an approach that has proved to be encouraging. Significantly, it makes use of resources that are already available in every school in the world.

\section{Framework}

\subsection{Mobilising available resources}

The research we report focusses attention on making more effective use of available human resources to promote inclusion in schools. It places teachers and the development of their practices at the centre of these efforts. It follows the position that teacher professional learning is crucial for promoting inclusion (Messiou \& Ainscow, 2015).

In recent years, 'professional development' and 'professional learning' have replaced terms such as 'in-service training' and 'staff development' (Bleicher, 2014; Jaipal \& Figg, 2011) that have been used in the past. Through her review of studies on teacher professional development, Avalos (2011) highlights collaboration as a facilitator for learning amongst teachers, in particular for altering or reinforcing their practices. In addition, Hayes (2000) suggests that effective teacher development can be promoted if and when used in line with collaborative and context-specific involvement of teachers, who have ownership over their personal development. These are factors that were taken into account in the programme of research that we describe in this article.

There is, however, another set of human resources that are often overlooked when thinking about the development of inclusive education, that of children and young people themselves. This leads us to ask: what roles can they take to lead to the improvement of teaching and learning in classrooms?

The idea of 'students' voices' offers a useful starting point. This term encompasses a range of meanings, from expression of views, either verbally or non-verbally, to active participation in decision-making. Thomson (2008) defines voice as: "Having a say, as well 
as referring to language, emotional components as well as non-verbal means that are used to express opinions" (p. 4). Meanwhile, Alexander (2010) suggests that the notion of voice is "complex and can be used in various ways, reflecting different contexts, aims and beliefs" (p.144). Similarly, Fielding (2006) argues that the term includes a range of activities encouraging the involvement of young people. In our own work, inclusion and student voice are seen as being interconnected ideas (Messiou, 2019), with inclusion referring to the removal of barriers to the presence, participation and achievement of all learners (Ainscow, 2007).

Building on these ideas, and drawing on lessons from our earlier work (e.g. Ainscow et al., 2004, 2006; Messiou, 2003, 2006a, 2006b, 2012), we designed two interconnected studies, each funded by the European Union. In what follows, we explain the two studies, before presenting specific examples of what the approach involves.

\subsection{Developing Inclusive Inquiry}

The first study "Responding to diversity: a strategy for teacher development" (20112014), involved eight secondary schools in three European countries (England, Portugal, Spain), whilst the second study, "Reaching the 'hard to reach': inclusive responses to diversity through child-teacher dialogue" (2017-2020), involved developments in 30 primary schools, in five European countries (Austria, Denmark, England, Portugal, Spain).

The methodology employed in both studies was that of collaborative action research focused on educational improvement (McNiff \& Whitehead, 2010). It has been argued that most studies based on this approach primarily focus on collaboration between teachers, or between teachers and researchers, whereas collaboration between students and teachers has not often been used (Hadfield \& Haw, 2001).

In the studies we report here the focus was on student-teacher collaboration. In addition, university researchers worked alongside teachers and students in these schools, supporting schools, whilst at the same time monitoring developments by collecting and analysing data in order to monitor implementation and determine the impact.

What distinguishes these studies from much of traditional research in the area of educational improvement is that they share a commitment to the following processes:

- An engagement with the views of different stakeholders, in the belief that the bringing together of the perspectives of practitioners and students can challenge taken-for-granted assumptions, not least in respect to vulnerable groups of learners. This is based on the findings of research which suggests that listening to a range of voices can stimulate new thinking, and encourage experimentation with different ways of working (e.g. Ainscow et al., 2012; Deppeler, 2013; Messiou, 2012).

- Collaboration and networking within and across classrooms and schools in order to move expertise around (Chapman et al., 2016; Muijs, West, \& Ainscow, 2010). This links to a range of research that demonstrates the potential of networking, collaboration, and building the social capital of the school as a way of improving both equity and academic outcomes in schools (e.g. Ainscow, 2016; Caldwell \& Harris, 2008; Earl \& Katz, 2007). 
- Improving practice within school contexts through the sharing of expertise, joint practice development and forms of collaborative action that stimulate efforts to find more effective ways of engaging "hard-to-reach" students (e.g. Hiebert et al., 2002; Lo et al., 2005; Messiou \& Ainscow, 2015; Sandoval \& Messiou, 2020).

In what follows, we summarise how these ideas were used within the two studies.

\section{The process}

\subsection{Responding to diversity: a strategy for teacher development}

This first study took place in eight secondary schools in three European countries and led to the development of a new model for the development of learning and teaching that we now refer to as 'inclusive inquiry' (Messiou \& Ainscow, 2015; Messiou et al., 2016). The model involves four interconnected processes: talking about diversity; learning from experiences; developing inclusive practices; and engaging with students' views. The idea of engaging with the views of students is the most important element in this process.

The initial version of the model emerged from combining two approaches: a form of the lesson study approach and a framework for engaging with the views of students. Lesson study is a well-established approach for teacher development widely used in Japan and several other Asian countries (Hiebert et al., 2002; Lewis et al.,2006) and more recently in various other countries (e.g. Dudley, 2013; Mewald \& Mürwald-Scheifinger, 2019). Teachers form groups, usually trios where they design a lesson together, then one of the teachers teaches it, whilst the others observe. The process is repeated three times with the aim being that of refining the lesson. The other approach that was combined with lesson study, was a framework that focuses on an engagement with students' voices as a way of understanding marginalisation and promoting inclusion (Messiou, 2012).

\subsection{Reaching the hard to reach': inclusive responses to diversity through child- teacher dialogue.}

The second study took place in primary schools in five European countries. It further refined the model that emerged from the previous study and trialled its use in a total of thirty primary schools. Whereas the focus of the first study was on an engagement with students' voices, this second study explored and highlighted the importance of studentteacher dialogues in schools as central feature (Messiou \& Ainscow, 2020), as illustrated in the Figure 1. 


\section{Figure 1}

\section{Inclusive Inquiry}

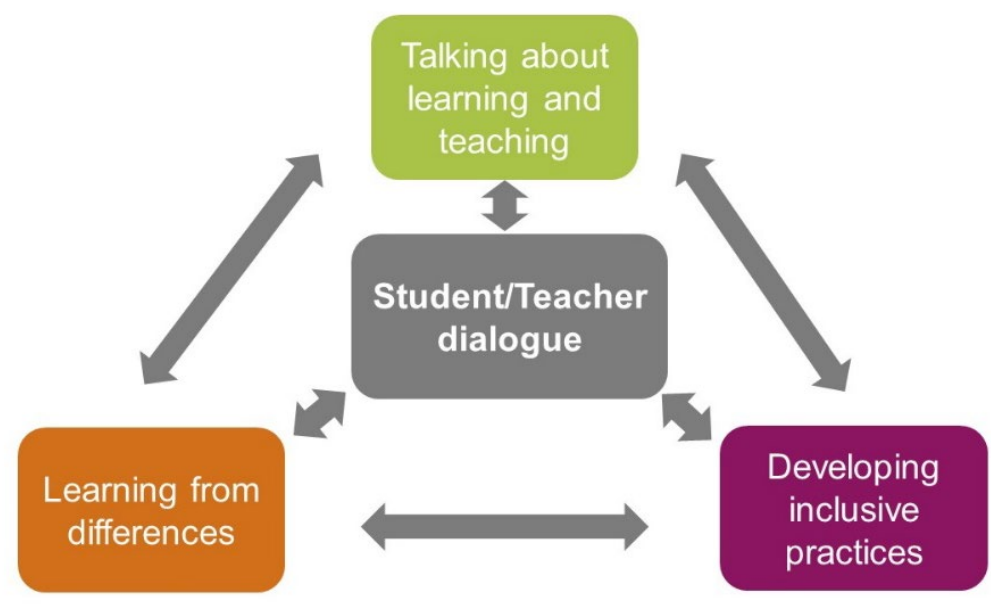

In what follows we explain what the elements of this formulation involve, as well as describing how they interact as the approach is used in schools.

\subsection{Inclusive Inquiry}

The elements shown in Figure 1 interact within a dynamic process that has to be adapted to particular contexts. In practice, this involves three distinct phases: Plan, Teach and Analyse. Each phase involves a series of steps, as illustrated in the Figura 2.

\section{Figura 2}

\section{Process phases of inclusive inquiry}

\begin{tabular}{l} 
The Levels of Use Framework \\
\hline Phase 1: Plan \\
\hline 1.1 A trio of teachers has been formed to carry out action research \\
1.2 The trio has agreed about which will be their research lesson \\
\hline 1.3 The trio has involved a group of student researchers in collecting evidence to support the design of the research lesson \\
\hline 1.4 A lesson plan has been developed that sets out to ensure that all members of the class are engaged in all the activities \\
\hline 1.5 The three teachers and the student researchers have all contributed to the design of the lesson plan \\
\hline Phase 2: Teach \\
\hline 2.1 Each teacher has used the lesson plan with their class \\
\hline 2.2 On each occasion, the two colleagues and student researchers observed the responses of class members \\
\hline 2.3 The views of all students about the lesson were gathered \\
\hline $\begin{array}{l}\text { 2.4 After each lesson, teachers and student researchers met to review what has happened, focusing on the engagement of } \\
\text { all members of the class }\end{array}$ \\
\hline 2.5 The trio refined the lesson plan before it was used by the next member of the trio \\
\hline Phase 3: Analyse \\
\hline 3.1 After completing all three lesson plans, the trio and student researchers discussed their impact on the engagement of \\
all members of the classes \\
\hline 3.2 The trio and student researchers drew conclusions regarding what was been learned about making lessons inclusive
\end{tabular}

When using Inclusive Inquiry, teachers form trios in order to design what is called a research lesson, the aim of which is to find ways of reaching out to all learners in the class. Each teacher chooses three (or more) students from their class who are seen in some way as being 'hard to reach', who become researchers. These may be children who have been 
defined as having special educational needs, refugees, children from disadvantaged backgrounds, or others who lacked confidence in school or who struggle with learning.

These decisions are left to the teachers and their perceptions of who is seen as 'hard to reach' in lessons. These students are then trained by their teachers in order to become researchers. This training focuses on familiarising students with methods for collecting their classmates' views about learning and teaching, as well as introducing them to methods for carrying out observations of lessons.

Following the training, the teams of student researchers collect their classmates' views about learning and teaching, using their preferred methods, such as voting, interviews or the use of visual images. The information that they collect is then analysed by the student researchers to inform the planning of the research lesson, which is carried out in cooperation with the trio of teachers. This planning process involves the nine student researchers cooperating with the three teachers.

The lesson is then taught in each of the classes by one of the teachers. What happens is observed by the two partner teachers and by student researchers from the other two classes. At the end of each lesson, the student researchers collect the views of the whole class about the lesson. Then discuss what they have observed with the trio of teachers, in addition to what their classmates thought, in order to make modifications for the next time the lesson is taught. The focus of the observations and of the discussions that follow the lesson is on finding ways to ensure that all learners are included in the learning process.

\section{Findings}

\subsection{Developing inclusion and teacher professional learning}

In what follows, three cameos from primary and secondary schools in different countries are used in order to illustrate how Inclusive Inquiry can help to promote inclusion in schools and teacher professional learning. In particular, this leads us to explore the following questions:

- In what ways does inclusive inquiry promote teacher professional learning?

- What is the impact on students and teachers?

- How does this facilitate the development of inclusive practices in schools?

(i) Making sense of collaboration: Following the gathering of all students' views about learning and teaching in a Portuguese secondary school, a trio of teachers worked with student co-researchers in the planning of the research lesson. In choosing the coresearchers the teachers ensured that they had students from both genders with a range of perceived abilities and students with different behaviour profiles. Together, the teachers and students collaborated to make sense of all the suggestions that they generated in order to ensure that they were implementing these when designing their research lesson.

Reflecting on the activities that she ended up using in her own classroom as a result of this collaboration, one teacher commented:

Before, for me, collaborative work just meant task division. I have learned to work in collaboration and I gave it a new importance and priority. I have recognised how 
much it can be stimulating and motivating to try out new possibilities. If it was not in collaboration a lot of the classroom activities that I have used wouldn't have just happened.

The issue that this teacher highlighted here is crucial, since collaboration can indeed be seen as being 'task division'. In addition, it seems that through this collaboration this teacher developed new activities that she would have not used otherwise.

(ii) Engaging with matters of detail: In a secondary school in Spain, a teacher explained how she changed her practices as a result of observing her colleagues' teaching and analysing the lessons afterwards:

Observations also were very, very interesting and I think we shall try to make all he school do the same process, going through observation of all the teachers 'cause you learn.

She went on to explain:

One of the things they say is we need teachers to be more (...) less stressed, talking in a specific way and all that. When you observe all the teachers we will be taking care of those specific areas, you see that how he's talking or she's like asking the students or, and being calm, you observe things that when you are teaching you are not aware of so that was very interesting and we made the students raise their hands, we raise our hands for everybody, it's the polite sign also because we have the students, so instead of saying "ok, you haven't raised your hand, you've raised your hand". No, we say (...) thank you for raising your hand to the one that is raising it and that makes the whole class stop so those little things for us are also important and because the students were saying those things and planning in that way and also observing each other help us and all.

What was interesting here was the way that a taken for granted everyday practice, such as that of praising students that put their hands up, or drawing attention to some students that they had not put their hands up, was rethought based on the observations. This then led the teacher to act differently in order to ensure greater participation of students.

(iii) Promoting dialogue: This example, which comes from a primary school in England, involved a trio of teachers and third-year students ( 8 years old children). The topic that they explored was Rainforests, in particular deforestation.

Following the training of a group of students as researchers, a detailed discussion took place to design the lesson. The discussion started by focusing on what helps with students' learning. A number of features were discussed, such as using drama and watching video clips. The lesson objectives were to understand why the forests are removed and the effects of that, focusing on conflicting views of deforestation. These were explained to the student researchers in order to start designing lesson.

After discussions between the teachers and student researchers it was decided that the lesson was going to include a drama activity, where children would be asked to take different roles in groups such as: pharmacist, conservationist, loggers, cattle farmers, government officials, Southampton child and fast-food restaurant owner. They would be asked to create a scene in their group that would support a specific view about deforestation, based on which role they had taken. They would then act out the scene in their group. Children were given the option to write a script before acting out the scene. Later, they would perform the scene in front of the rest of the class.

The lesson was taught three times, followed by analysis at the end of each lesson in order to make notifications for the next lesson. At the end of lesson two, one of the areas 
discussed was one of the changes that were introduced after the analysis of lesson one: that of having students working in bigger groups. In lesson one, the students had been asked to work in groups of four. After discussing whether or not this worked, it was decided to create even smaller groups:

Teacher: Do you think having bigger groups helped those guys learn today or did it not, why? (children are given a minute to discuss in pairs). OK, so what do you think?

Student 1: I think smaller because it's really hard to organise all the people.

Teacher: Okay. Can I say how well you articulated that, that's a brilliant idea. So, you find it quite hard for the groups to actually organise who is saying what, and it's quite tremendous to write down isn't it.? Okay. J.?

Student 2: I think like I think it was not really good having a big group because some of them like fussing about who true, who wrong.

Teacher: Yeah, they were fussing a lot. They spent quite a lot of time fussing, didn't they?

Student 2: And they did not really get the things done so.

Teacher: $O K, G$ ?

Student 3: Small groups.

Teacher: So, we think the next lesson we are going to change the groups down straightaway. Change we're going back to eh how big we have the groups?

Students: Three.

Students: Four, four.

Teacher: Hand up for three, hand up for four. Okay, so in my class on Monday, we did four. When we came to $\mathrm{Mr}$. K class we had five. So we changed it to three and then we'd be able to work out which worked best.

One of the reasons that they had originally decided to have groups of five was to avoid having some children taking two roles for the scene that they prepared. However, the student researchers then realised how having more children in a group led to some not being involved actively in what they were preparing, as well being difficult to coordinate a bigger group. For the final lesson, they therefore decided to explore having only three children in a group, which seemed to work well, especially in relation to all children's engagement.

Another change that was introduced, both for lessons two and three, was asking all groups to prepare a script before acting out the scene, since it was agreed that the groups that had taken the time to write down a script and agree specific words that they were going to say, made the most convincing arguments in favour or against deforestation, depending on the role that they had taken. In this way, we saw how dialogue led to modifications that enabled improvements in student engagement.

\subsection{Implications}

Reflecting on the whole process of using Inclusive Inquiry, the teachers mentioned in these cameos commented on various issues, particularly the impact that the approach and the lessons that were designed had on particular children's engagement. For example, a teacher in cameo (iii) commented about one of the girls in his class saying:

She generally gets very nervous for any sort of performance, so like gym days she would refuse. So, I would make her perform in front of a group of her friends, or me and someone else. But when it came to this lesson, I didn't think it would be that much of 
an issue because it was a standard topic lesson but nothing too serious. So, she performed it in front of her friends and then she had the confidence to go and do it in front of the class.

The teacher explained how this particular student had to perform in front of her friends first, but then she also felt confident to perform in front of the whole class.

Discussing the longer-term implications for children who were involved in this process, one of the teachers in cameo (iii) said:

...what you can teach children is to think for themselves and take ownership of their
own work and to be more creative in what helps and what doesn't. And actually, to
acknowledge things in the wider world around them rather than just themselves. I
think this puts a different spin on it, in terms of what the children also get out of it
from what they can actually do later on in life. It teaches skills for them that they can
actually apply in other lessons, and having choice in lessons, but being creative in itself.
But having those children be like "what would you like to do?", or "Oh, that didn't
work. What can we do now?" So, it's that resilience and perseverance and problem
solving that we as teachers find really hard to do anyway with that many children.
So, I think it's really just about honing it in.

Here, this teacher focuses in a reflective way on the benefits of using Inclusive Inquiry in terms of the development of the skills of students. It is interesting, too, to note that this teacher pointed out pressures of time within school. In particular, she explained, this makes it difficult for teachers to achieve the development of skills, such as resilience, perseverance and problem solving, due to having so many children in the class. These are skills that she felt that children developed through the use of Inclusive Inquiry.

As we have seen in the cameos we have presented, using Inclusive Inquiry, with its emphasis on collaborative dialogue, led to rethinking and, in some cases, this also led to significant changes in practices. The impact of collaboration on teacher learning has been highlighted in other studies (e.g. Avalos, 2011; Cordingley et al., 2005; Hill et. al., 2013). However, what is distinctive here, is the fact that this collaboration was the result of student-teacher collaboration.

\subsection{Impacts}

Our monitoring of what happened in the schools involved in the research led us to assess the impacts (Messiou \& Ainscow, 2020). Most significantly, there was evidence from all the countries that the involvement of students in Inclusive Inquiry led to students being more engaged in lessons and more positive about themselves as learners.

These impacts were more noticeable amongst those students who had taken the role of researchers. However, in some schools, teachers reported how they noticed similar impacts on other members of their classes. It was explained that students, in general, seemed to see themselves as having more active roles within classroom activities. This was a result of contributing ideas to the way lessons were designed, as well as sharing their thoughts at the end of each lesson, that the student researchers and teachers were considering for the analysis of each of the lessons.

Some teachers mentioned how they some children 'becoming more autonomous' learners. Others talked about how students had developed a greater ownership of their learning. One teacher summarised the views of many others when she said, "I have never seen my children so involved". 
In some schools, it was noticed how giving students' choice within lessons regarding activities had helped to foster this increased sense of engagement amongst students. Teachers also talked about how this had led them to have greater sensitivity towards the preferences of children.

Across the countries there was particularly strong evidence of the way that being a student researcher had impacted on individuals. Many of these children felt proud when asked take on this role. For example, one student in Austria said:

$$
\begin{aligned}
& \text { I was surprised that I was selected. I am happy that I can help other children. It felt } \\
& \text { very good to be a researcher. }
\end{aligned}
$$

Taking this role led to improvements in their self-confidence. For example, one student in England said:

$$
\begin{aligned}
& \text { Before I was a pupil researcher, when teacher asked anyone to answer the questions, I } \\
& \text { never put my hand up because I did not have my confidence. And when I was a pupil } \\
& \text { researcher, I put my hand up. }
\end{aligned}
$$

Here it is worth noting that these students had been chosen because they were, in some way or other, seen as being 'hard to reach' by their teachers. Some of these were children viewed as being shy or socially marginalized within their classes. Others were students with long records of difficult behavior, some of whom were seen to become far more integrated into their school. As teachers explained, for some of these children various attempts to ensure that they are included in lessons were not successful. Being involved in Inclusive Inquiry was significant in this respect.

It was also interesting to hear some of these children talk with sensitivity about the demands on their teachers. Indeed, some talked about their realization of how hard their teachers work as a result of being involved with them in lesson planning.

Many teachers talked of the value of planning and reviewing lessons with their colleagues and with the student researchers. Having opportunities to see other teachers at work was particularly valued. For example, teachers in Portugal commented:

Teacher 2: It was the strengthening of the connection of the three of us. Confidence. The increase in confidence in the work. To know that when one needs support the others are present. I think this work has brought us together a lot.

Teacher 1: There was a closeness because, although this was somewhat informal, we felt the weight of responsibility and supported each other. And it also led to moments of personal and group reflection, so that we could better achieve the goal of all the students participating equally, of learning in the best possible way.

Here, we can see how relationships between teachers became stronger as a result of working together in teams, sharing a common responsibility that required of them to support one another.

This reminds us of the professional isolation that still exists amongst teachers in many schools. Getting to know what other colleagues do led to the sharing of expertise and resources. It also helped to make the familiar unfamiliar, as teachers focused on and discussed matters of detail, such as instructions for carrying out tasks, forms of groupwork and the use of feedback to students. For example, one teacher commented: "It's the small things that matter", whilst another teacher noted: "We see things we do not notice when we lead the class". 
Having student perspectives on these issues added a different dimension and brought greater challenge to the discussions, such that, sometimes, the taken for granted assumptions of adults regarding what makes learning possible were challenged. This, in turn, made one teacher in Denmark express "surprise on what children can offer". In some instances, it also led teachers to become more sensitive regarding individual students and how they experience classroom life.

In some schools, teachers commented how they had moved from their initial focus on asking students to provide feedback on their lessons towards more constructive forms of dialogue. This had stimulated creativity and experimentation in order to explore more inclusive forms of teaching and learning.

There was also evidence of the way that the introduction of inclusive Inquiry led to changes in the life of schools. Teachers in some schools talked about how it had helped create greater democracy within their school communities, as adults saw the potential of their students to help foster improvements. Some teachers also referred to changes in the cultures of their schools. This was a process that implied deeper changes in attitudes and beliefs as to what might be possible, particularly with students who had previously been seen as problems. In practical terms, this involved changes in relationships: between teachers; between students; and, crucially, between teachers and their students.

\section{Conclusion}

The evidence from these studies of the development of Inclusive Inquiry supports our earlier research which suggested that classroom-based research carried out by practitioners can be a powerful way of moving practice forward within a school (Ainscow et al., 2012). What is distinctive, however, is the added value that comes from engaging students themselves in the process.

At the same time, it is important to stress that the use of the approach can present various organisational challenges. In particular, it sometimes proved to be challenging of the status quo within schools. Consequently, greater collaboration is needed amongst teachers in order to support the introduction of new practices. This requires organizational flexibility and the active support of senior staff, prepared to encourage and support processes of experimentation. Indeed, it implies the need for cultural change within a school, which is likely to have deeper and longer-term benefits in relation to the promotion of inclusion in schools.

This indicates that inclusion is less about the introduction of particular techniques, or new organizational arrangements, and much more about processes of social learning within particular contexts. In this respect, an engagement with evidence as a means of stimulating experimentation and collaboration is a central strategy. As Copland (2003) suggests, inquiry can be the 'engine' to enable the distribution of leadership that is needed in order to foster participation in learning, and the 'glue' that can bind a community together around a common purpose.

All of this has major implications for leadership practice within schools and education systems. In particular, it calls for efforts to encourage coordinated and sustained efforts around the idea that changing outcomes for vulnerable groups is unlikely to be achieved unless there are changes in relationships between teachers and students. 


\section{References}

Ainscow, M. (2007). From special education to effective schools for all: A review of progress so far. In L. Florian (Ed.), The SAGE handbook of special education (pp. 146-159). SAGE.

Ainscow, M. (2016). Collaboration as a strategy for promoting equity in education: Possibilities and barriers. Journal of Professional Capital and Community, 1(2),159-172. https://doi.org/10.1108/JPCC-12-2015-0013

Ainscow, M., Booth, T., \& Dyson, A. (2004). Understanding and developing inclusive practices in schools: A collaborative action research network. International Journal of Inclusive Education, 8(2), 125-140. https://doi.org/10.1080/1360311032000158015

Ainscow, M., Booth, T., Dyson, A., Farrell, P., Frankham, J., Gallannaugh, F., Howes, A., \& Smith, R. (2006). Improving schools, developing inclusion. Routledge.

Ainscow, M., Dyson, A., Goldrick, S., \& West, M. (2012). Developing equitable education systems. Routledge

Alexander, R. (2010). Children, their world, their education. Final report and recommendations of the Cambridge primary review. Routledge.

Ávalos, B. (2011). Teacher professional development in teaching and teacher education over ten years. Teaching and Teacher Education, 27, 10-20. https://doi.org/10.1016/j.tate.2010.08.007

Bleicher, R. E. (2014). A collaborative action research approach to professional learning. Professional Development in Education, 4O(5), 802-821.

https://doi.org/10.1080/19415257.2013.842183

Caldwell, B., \& Harris, J. (2008). Why not the best schools? ACER Press.

Copland, M. A. (2003). Leadership of inquiry: Building and sustaining capacity for school improvement. Educational Evaluation and Policy Analysis, 24(4), 375-475. https://doi.org/10.3102/01623737025004375

Cordingley, P., Bell, M., Evans, D., \& Firth, A. (2005). The impact of collaborative CPD on classroom teaching and learning. EPPI-Centre, Institute of Education.

Chapman, C., Chestnutt, H., Friel, N., Hall, S., \& Lowden, K. (2016). Professional capital and collaborative inquiry networks for educational equity and improvement? Journal of Professional Capital and Community, 1(3),178-197.

https://doi.org/10.1108/JPCC-03-2016-0007

Deppeler, J. (2013). Developing equitable practices in schools: professional collaboration in research. In P. Jones (Ed.), Bringing insider perspectives into inclusive teacher learning: Potentials and challenges for educational professionals (pp. 178-188). Routledge.

Dudley, P. (2013). Teacher learning in lesson study: What interaction-level discourse analysis revealed about how teachers utilised imagination, tacit knowledge of teaching and fresh evidence of pupils learning, to develop practice knowledge and so enhance their pupils' learning. Teaching and Teacher Education, 34,107-121. https://doi.org/10.1016/J.TATE.2013.04.006

Earl, L., \& Katz, S. (2007). Leadership in networked learning communities: Defining the terrain. School Leadership and Management, 27(3), 239-258. https://doi.org/10.1080/13632430701379503 
Fielding, M. (2006). Leadership, radical student engagement and the necessity of person-centred education. International Journal of Leadership in Education, 9(4), 299-313. https://doi.org/10.1080/13603120600895411

Hadfield, M., \& Haw, K. (2001). Voice young people and action research. Educational Action Research, 9(3), 485-502. https://doi.org/10.1080/09650790100200165

Hayes, D. (2000). Cascade training and teachers' professional development. English Language Teaching Journal, 54(2), 135-145. https://doi.org/10.1093/elt/54.2.135

Hiebert, J., Gallimore, R., \& Stigler, J.W. (2002). A knowledge base for the teaching profession: What would it look like and how can we get one? Educational Researcher, 31(5), 3-15. https://doi.org/10.3102/0013189X031005003

Hill, H. C., Beisiegel, M., \& Jacob, R. (2013). Professional development research. Consensus, crossroads, and challenges. Educational Researcher, 42(9), 476-487.

https://doi.org/10.3102/0013189X13512674

Jaipal, K., \& Figg, C. (2011). Collaborative action research approaches promoting professional development for elementary school teachers. Educational Action Research, 19(1), 59-72. https://doi.org/10.1080/09650792.2011.547688

Lewis, C., Perry, R., \& Murata, A. (2006). How should research contribute to instructional improvement? The case of lesson study. Educational Researcher, 35(3), 3-14. https://doi.org/10.3102/0013189X035003003

Lo, M. L., Yan, P. W., \& Pakey, C. (2005). For each and everyone: Catering for individual differences through learning studies. Hong Kong University Press.

McNiff, J., \& Whitehead, J. (2010). You and your action research project. Routledge

Messiou, K. (2006a). Conversations with children: Making sense of marginalisation in primary school settings. European Journal of Special Needs Education, 21(1), 39- 54.

Messiou, K. (2006b). Understanding marginalisation in education: The voice of children. European Journal of Psychology of Education, 21(3), 305-318. https://doi.org/10.1007/BF03173418

Messiou, K. (2012). Confronting marginalisation in education: A framework for promoting inclusion, Routledge.

Messiou, K. (2019). The missing voices: Students as a catalyst for promoting inclusive education. International Journal of Inclusive Education, 23(7), 768-781. https://doi.org/10.1080/13603116.2019.1623326

Messiou, K., \& Ainscow, M. (2015). Responding to learner diversity: Student views as a catalyst for powerful teacher development? Teaching and Teacher Education, 51, 246-255. https://doi.org/10.1016/j.tate.2015.07.002

Messiou, K., \& Ainscow, M. (2020). Inclusive inquiry: Student-teacher dialogue as a means of promoting inclusion in schools. British Educational Research Journal, 46(3), 670-687. https://doi.org/10.1002/berj.3602

Messiou, K., Ainscow, M., Echeita, G., Goldrick, S., Hope, M., Paes, I., Sandoval, M., Simón, C., \& Vitorino, T. (2016). Learning from differences: A strategy for teacher development in respect to student diversity. School Effectiveness and School Improvement, 27(1), 45-61. https://doi.org/10.1080/09243453.2014.966726

Mewald, C., \& Mürwald-Scheifinger, E. (2019). Lesson study in teacher development: A paradigm shift from a culture of receiving to a culture of acting and reflecting. European Journal of Education, 54, 218-232. https://doi.org/10.1111/ejed.12335 
Muijs, D., West, M., \& Ainscow, M. (2010). Why network? Theoretical perspectives on networking. School Effectiveness and School Improvement, 21(1), 5-26. https://doi.org/10.1080/09243450903569692

OECD. (2012). Equity and quality in education: Supporting disadvantaged students and schools. OECD.

Sandoval, M., \& Messiou, K. (2020). Students as researchers for promoting school improvement and inclusion: a review of studies. International Journal of Inclusive Education. https://doi.org/10.1080/136031 16.2020.1730456

Thomson, P. (2008). Doing visual research with children and young people. Routledge.

UIS. (2019). Fact sheet no. 56. http://uis.unesco.org/sites/default/files/documents/newmethodology-shows-258- million-children-adolescents-and-youth-are-out-school.pdf

UNESCO. (2015). Incheon declaration and framework for action for the implementation of sustainable development goal 4. UNESCO

UNESCO. (2020). Global education monitoring report 2020. Inclusion and education: All means all. UNESCO.

\section{Breve CV del/a autor/a}

\section{Kyriaki (Kiki) Messiou}

Professor of Education within Southampton Education School at the University of Southampton. Her research interests are in the area of inclusive education and, in particular, in exploring children's and young people's voices to understand notions of marginalisation and develop inclusive practices in schools. She is particularly interested in research with children and young people and methodological issues related to this issue. Kiki is a regular contributor to international conferences, such as AERA, BERA and ECER. She has presented invited keynote presentations in various countries, such as Cyprus, Spain, Austria and South Africa. She has led big teams of international researchers in the field of inclusive education. Kiki started her career as a primary school teacher in Cyprus and completed her postgraduate studies at the University of Manchester. She has extensive experience of working in schools as a teacher and as a researcher. In universities she developed and led undergraduate and postgraduate courses about inclusive education. She also established a research centre involving researchers and practitioners. Email: k.messiou@soton.ac.uk

ORCID ID: https://orcid.org/o000-0003-3412-3108

\section{Mel Ainscow}

Emeritus Professor of Education, is internationally recognized as an authority on the promotion of inclusion and equity in education. Previously a head teacher, local education authority adviser and lecturer at the University of Cambridge, his work focuses on ways of making schools effective for all children and young people. A distinctive feature of his approach is the emphasis he places on carrying out research with schools and education systems to promote improvements. Professor of Education at the University of Glasgow, Adjunct Professor at Queensland University of Technology and Honorary Professor of Practice at University of Wales Trinity Saint David. He has published extensively in practitioner and international research journals. Is currently working to promote equity and inclusion globally. He is also a consultant to an initiative organised by the Organization of American States, which is supporting national developments in nine 
Latin American countries. He has recently completed collaborative research projects with networks of schools in five European countries. Email: mel.ainscow@manchester.ac.uk

ORCID ID: https://orcid.org/0000-0002-0449-9668 